Communication

\title{
Enzyme Inhibitory Radicinol Derivative from Endophytic fungus Bipolaris sorokiniana LK12, Associated with Rhazya stricta
}

\author{
Abdul Latif Khan ${ }^{1}$, Liaqat Ali ${ }^{1, *}$, Javid Hussain ${ }^{1,2}$, Tania Shamim Rizvi ${ }^{1}$, \\ Ahmed Al-Harrasi ${ }^{1,2, *}$ and In-Jung Lee ${ }^{3}$ \\ 1 UoN Chair of Oman's Medicinal Plants and Marine Natural Products, University of Nizwa, \\ Birkat Al-Mouz, Nizwa 616, Oman; E-Mails: abdullatif@unizwa.edu.om (A.L.K); \\ javidhej@unizwa.edu.om (J.H.); tania@unizwa.edu.om (T.S.R.) \\ 2 Department of Biological Sciences and Chemistry, College of Arts and Sciences, \\ University of Nizwa, Birkat Al-Mouz, Nizwa 616, Oman \\ 3 School of Applied Biosciences, Kyungpook National University, Daegu 702-701, Korea; \\ E-Mail: ijlee@knu.ac.kr
}

* Authors to whom correspondence should be addressed; E-Mails: malikhejric@gmail.com (L.A.); aharrasi@unizwa.edu.om (A.A.-H.); Tel.: +968-2544-6608 (L.A.).

Academic Editor: Isabel C.F.R. Ferreira

Received: 3 May 2015 / Accepted: 30 June 2015 / Published: 3 July 2015

\begin{abstract}
Endophytes, living inside plant tissues, play an essential role in plant growth and development, whilst producing unique bioactive secondary metabolites. In the current study, the endophytic fungus Bipolaris sorokiniana LK12 was isolated from the leaves of ethno-medicinal and alkaloidal rich Rhazya stricta. The bulk amount of ethyl acetate extract of fungus was subjected to advance column chromatographic techniques, which resulted in the isolation of a new radicinol derivative, bipolarisenol (1). It was found to be a derivative of radicinol. The structure elucidation was carried out by the combined use of $1 \mathrm{D}$ and $2 \mathrm{D}$ nuclear magnetic resonance, infrared spectroscopy, mass, and UV spectrometric analyses. The bipolarisenol was assessed for its potential role in enzyme inhibition of urease and acetyl cholinesterase (AChE). Results showed that bipolarisenol significantly inhibited the AChE activity with low $\operatorname{IC}_{50}\left(67.23 \pm 5.12 \mu \mathrm{g} \cdot \mathrm{mL}^{-1}\right)$. Bipolarisenol inhibited urease in a dose-dependent manner with high $\mathrm{IC}_{50}\left(81.62 \pm 4.61 \mu \mathrm{g} \cdot \mathrm{mL}^{-1}\right)$. The new compound also showed a moderate anti-lipid peroxidation potential $\left(\mathrm{IC}_{50}=168.91 \pm 4.23 \mu \mathrm{g} \cdot \mathrm{mL}^{-1}\right)$.
\end{abstract}


In conclusion, endophytes isolated from medicinal plants possess a unique potential to be considered for future drug discovery.

Keywords: radicinol; bipolarisenol; Rhazya stricta; Bipolaris sorokiniana LK12; lipid peroxidation; enzyme inhibition

\section{Introduction}

Endophytic microbes (bacteria and fungi) live inside plant tissues without causing any symptoms of disease to the host. Endophytic fungal association extends benefits to the plants by changing the endogenous mineral nutrients and metabolites levels [1]. During symbiosis, these endophytes produce metabolites inside plant tissues to help in the improvement of plant defenses against environmental stresses [2-5]. A significant number of interesting molecules have been produced by endophytes, including flavonoids, peptides, alkaloids, steroids, phenolics, terpenoids, lignans, and volatile organic compounds with many of them biologically active [5,6]. In fact, a previous study by Schulz et al. [6] showed that about 51\% of biologically active metabolites originate from endophytes compared to only $38 \%$ of novel substances originating from other soil microflora. In the past two decades, many novel bioactive compounds with antimicrobial, insecticidal, cytotoxic, and anticancer properties have been successfully isolated and characterized from endophytic fungi $[4,7]$.

One of the interesting examples of endophytic bioactive secondary metabolites is the production of the world's first billion dollar anticancer drug, paclitexel (taxol). Although it was initially reported from Taxus brevifolia, later it was also isolated from various endophytes (Taxomyces andreanae, Botryodiplodia theobromae, and Pestalotiopsis microspore etc.) living in symbiosis with the host [8]. The endophyte colonizes the Himalayan yew tree without causing apparent injury to the host plant. This potential has set the stage for increasing interest in fungal endophytes [3,9]. Looking at this potential, in the current study Rhazya stricta Decne was selected for its endophytic microbes and their potential to produce bioactive metabolites. $R$. stricta grows wildly in various countries of South Asia and the Middle East. It is a medicinal plant largely known for its alkaloidal content [10]. More than 100 different alkaloids have been reported from this plant $[11,12]$. Some of the chemical constituents have a potent function in various pharmacological activities.

Since the host $R$. stricta was found rich in diverse kinds of secondary metabolites, we aimed to explore its symbiotic endophytic fungi for similar potentials. The endophytic fungal diversity is yet to be explored from $R$. stricta. In the current study, a dark septet endophytic fungus, Bipolaris sorokiniana LK12 was isolated for the first time from the leaf part of $R$. stricta. The metabolites produced at extracellular level during the growth of $B$. sorokiniana were assessed using advanced chromatographic and NMR spectroscopic techniques. As a result, one new secondary metabolite belonging to radicinol class, bipolarisenol (1) (Figure 1), was purified and the chemical structure was elucidated. Furthermore, the purified constituent was subjected to biological assays to access the medicinal potential of the metabolite from endophyte $B$. sorokiniana. 


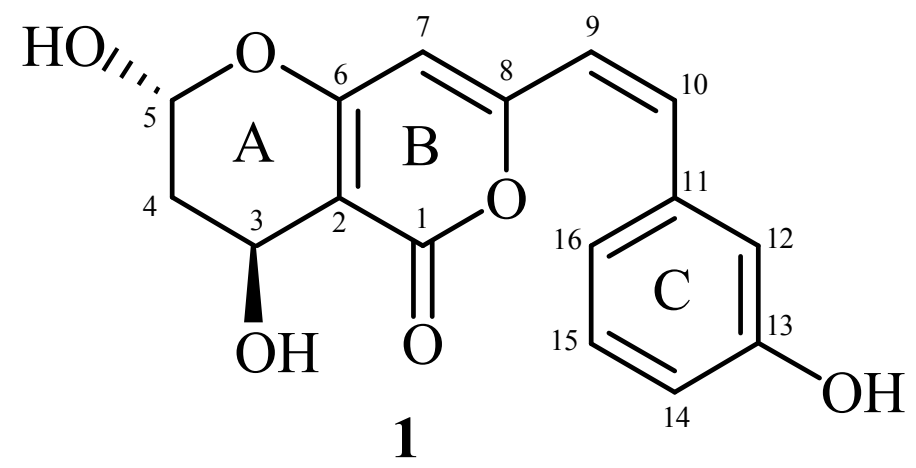

Figure 1. Structure of the new radicinol derivative, bipolarisenol (1).

\section{Results and Discussion}

The ethyl acetate extract obtained from the pure culture filtrate of endophytic fungus was assayed for possible bioactive role. Initial screening results showed that the extract (100 ppm) possessed significantly higher anti-lipid peroxidation potential $(51.28 \% \pm 0.97 \%)$. Further fractionation of the ethyl acetate extract resulted in the isolation of compound $\mathbf{1}$. Compound $\mathbf{1}$ was isolated as a colorless amorphous solid and the structure elucidation was carried out by the analysis of 1D and 2D NMR, MS, and IR spectral data along with comparison of the related NMR and MS data in literature [13,14].

The IR spectrum of compound 1 exhibited absorption bands at $3595(\mathrm{OH}), 1695(\mathrm{C}=\mathrm{O})$, and $1590 \mathrm{~cm}^{-1}(\mathrm{C}=\mathrm{C})$. The presence of hydroxyl groups was indicated by the IR band at $3595 \mathrm{~cm}^{-1}$. The UV maxima at 340 and $264 \mathrm{~nm}$ indicated the presence of conjugated aromatic system in the molecule [15]. The analysis of ESI-MS indicated the presence of pseudo molecular ions peak at $m / z 303.1574[\mathrm{M}+\mathrm{H}]^{+}$ (303.1570; calcd for $\mathrm{C}_{16} \mathrm{H}_{15} \mathrm{O}_{6}$ ) and $m / z 301.0715[\mathrm{M}-\mathrm{H}]^{-}\left(301.0712\right.$; calcd for $\mathrm{C}_{16} \mathrm{H}_{13} \mathrm{O}_{6}$ ), consistent with the molecular formula $\mathrm{C}_{16} \mathrm{H}_{14} \mathrm{O}_{6}$ for compound 1. The other prominent fragments in the mass spectrum were observed at $m / z 285[\mathrm{M}-\mathrm{OH}]^{+}, 284\left[\mathrm{M}-\mathrm{H}_{2} \mathrm{O}\right]^{+}, 209[\mathrm{M}-\mathrm{PhOH}]^{+}, 192$ $[\mathrm{M}-\mathrm{PhOH}-\mathrm{OH}]^{+}, 191\left[\mathrm{M}-\mathrm{PhOH}-\mathrm{H}_{2} \mathrm{O}\right]^{+}, 181,111$, and 69 , characteristics of radicinol derivatives with an additional aromatic ring in the molecule.

The ${ }^{1} \mathrm{H}-\mathrm{NMR}$ spectrum of $\mathbf{1}$ displayed signals in the aromatic region between $\delta 6.04$ to 7.98 ppm, whereas the aliphatic signals appeared between $\delta 3.01$ to $4.95 \mathrm{ppm}$. The values of chemical shift and coupling constants of the four aromatic resonances at $\delta 7.98(1 \mathrm{H}, \mathrm{d}, J=1.8 \mathrm{~Hz}, \mathrm{H}-12), 6.74(1 \mathrm{H}, \mathrm{d}$, $J=7.6 \mathrm{~Hz}, \mathrm{H}-14), 7.24(1 \mathrm{H}, \mathrm{t}, J=7.6 \mathrm{~Hz}, \mathrm{H}-15)$, and $6.82(1 \mathrm{H}, \mathrm{d}, J=7.8 \mathrm{~Hz}, \mathrm{H}-16)$ indicated the presence of a meta di-substituted benzene ring. The olefinic moiety in conjugation with the benzene ring was evident by the presence of two equally split doublets at $\delta 4.95$ and $7.18(1 \mathrm{H} \mathrm{each}, \mathrm{d}, J=14.1 \mathrm{~Hz}$, $\mathrm{H}-9 / \mathrm{H}-10)$. A one proton singlet at $\delta 6.03$ was assigned to $\mathrm{H}-7$, and consistent with the ${ }^{1} \mathrm{H}-\mathrm{NMR}$, the ${ }^{13} \mathrm{C}-\mathrm{NMR}$ data of 1 also displayed the methine type resonances at $\delta 96.3$ (C-7), 126.3 (C-9), 129.8 (C-10), 110.6 (C-12/14), 127.9 (C-15), and 121.4 (C-16). The downfield resonance at $\delta 170.4$ was assigned to the conjugated ester $\mathrm{C}-1$. The ${ }^{13} \mathrm{C}-\mathrm{NMR}$ and DEPT experiments also revealed the presence of three quaternary signals for ring $\mathrm{B}$ at $\delta 88.2$ (C-2), 169.0 (C-6), and 162.3 (C-8) and two quaternary signals for ring $\mathrm{C}$ at $\delta 137.3$ (C-11) and 165.0 (C-13). The ${ }^{1} \mathrm{H}-\mathrm{NMR}$ spectrum also showed the aliphatic resonances at $\delta 6.04(1 \mathrm{H}, \mathrm{dd}, J=3.4 / 6.7, \mathrm{H}-5), 4.34(1 \mathrm{H}$, br s, $\mathrm{H}-3), 3.15(1 \mathrm{H}, \mathrm{m}, \mathrm{H}-4 \mathrm{a})$, and $3.01(1 \mathrm{H}$, $\mathrm{m}, \mathrm{H}-4 \mathrm{~b}$ ), which were assigned to two oxy-methine and a methylene group of the dihydropyran ring A. These assignments were also confirmed by the signals in ${ }^{13} \mathrm{C}-\mathrm{NMR}$ spectrum at $\delta 108.5$ (C-5), 58.4 (C-3), 
and 35.3 (C-4). The attachment of various functional groups was assigned on the basis of HMBC interactions (Figure 2) of H-4 and C-3/C-5, H-7 and C-6/C-8, H-9 and C-8/C-10, H-10 and C-9/C-11, and $\mathrm{H}-14$ and $\mathrm{C}-13 / \mathrm{C}-15$. The substitution pattern of 1 was thus established and the structure was further confirmed through correlations observed in COSY and HMQC experiments. The relative stereochemistry was deduced on the basis of $J$ values and ${ }^{1} \mathrm{H}-{ }^{1} \mathrm{H}$ NOESY interactions of $\mathrm{H}-3$ to $\mathrm{H}-5$. Based on these spectral discussions, compound 1 was assigned as 3-O-acetyl-6,7,2'-trihydroxy-5,8dimethoxyflavanone, named bipolarisenol (1) after the producing organism, Bipolaris sorokiniana.

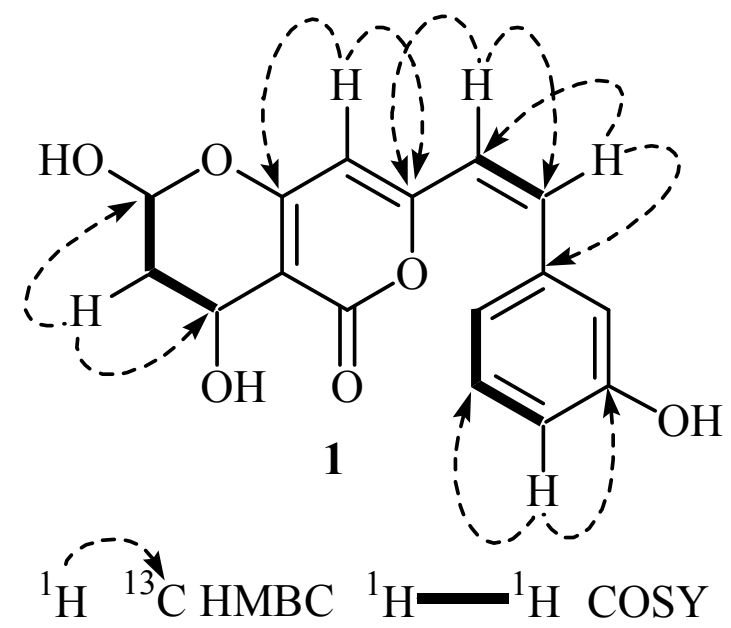

Figure 2. Key heteronuclear multiple bond correlation (HMBC) and important correlation spectroscopy (COSY) interactions in compound $\mathbf{1}$.

\section{Enzyme Inhibition and Anti-Lipid Peroxidation Activities}

After characterization of bipolarisenol through advance chromatographic and spectroscopic techniques, it was assessed for its potential in urease and acetyl cholinesterase enzymes inhibition. Urease (urea amidohydrolases, EC 3.5.1.5) is a thiol-rich and nickel-dependent metalloenzyme that can catalyze the hydrolysis of urea, thereby producing ammonia and carbamate [16]. Urease can be synthesized by numerous organisms, including plants, bacteria, algae, fungi, and invertebrates, and it also occurs in soils as a soil enzyme [17]. Importantly, ureolytic activity of bacteria, such as Proteus mirabilis, Klebsiella pneumoniae, Staphylococcus spp., Salmonella sp., and Ureaplasma urealyticum, is a vital virulence factor implicated in the pathogenesis of many clinical conditions, including pyelonephritis, hepatic coma, peptic ulceration, and formation of infection-induced urinary stones [18,19].

To explore remedies of such health problems, bipolarisenol was assessed using three different concentrations, while the inhibition response against each dose was analyzed by linear regression of dose-dependent enzyme inhibition curve fitting and presented in curve-fit graph (GraphPad prism 5.05, GraphPad Software, Inc., La Jolla, CA, USA). The inhibition pattern is given in detail in Figure 3. The results showed that compound 1 exhibited a dose-dependent response with $R^{2}$ values ranging above $70 \%$. A dose of 10 to $100 \mu \mathrm{g} \cdot \mathrm{mL}^{-1}$ revealed moderate suppression of urease enzyme with $\mathrm{IC}_{50}(81.62 \pm$ $4.61 \mu \mathrm{g} \cdot \mathrm{mL}^{-1}$ ) value suggesting that higher concentrations might help to completely hydrolyze the enzymatic activity. In continuation of previous work, natural products with flavonoids skeleton (quercetin glycosides) or their derivatives are possessing efficient inhibition potential against urease enzyme [20-22]. 


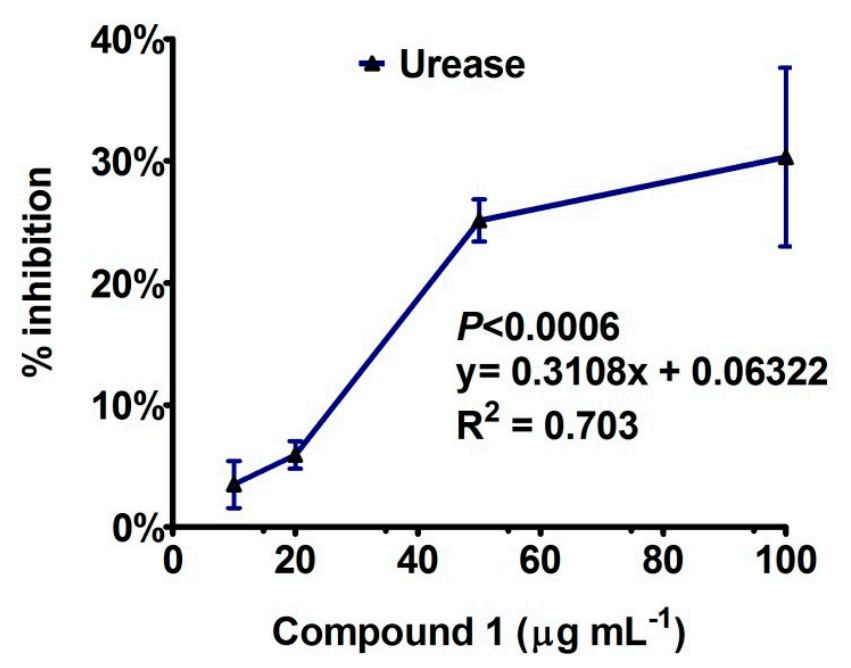

Figure 3. Urease inhibition activity of compound 1, isolated from endophytic fungus. The graphs showing values of three replication with standard error.

In case of acetyl cholinesterase inhibition, bipolarisenol was assayed, which showed a higher $R^{2}$ values for the curve-fit against 10 to $100 \mu \mathrm{g} \cdot \mathrm{mL}^{-1}$ (Figure 4). The response was dose-dependent. The IC50 value was low $67.23 \pm 5.12 \mu \mathrm{g} \cdot \mathrm{mL}^{-1}$. In response to 50 and $100 \mu \mathrm{g} \cdot \mathrm{mL}^{-1}$, the AChE inhibition curve was sharp with 67 and $88 \%$ of inhibition. AChE inhibition has been emerged as a major therapeutic target [23]. $\mathrm{AD}$ - galantamine, rivastigmine and donepezil are acetylcholinesterase inhibitors apart from the NMDA antagonist memantine [24]. Natural products have already proven to be promising sources of useful acetylcholinesterase (AChE) inhibitors $[25,26]$. Compound 1 could be a promising for similar potential.

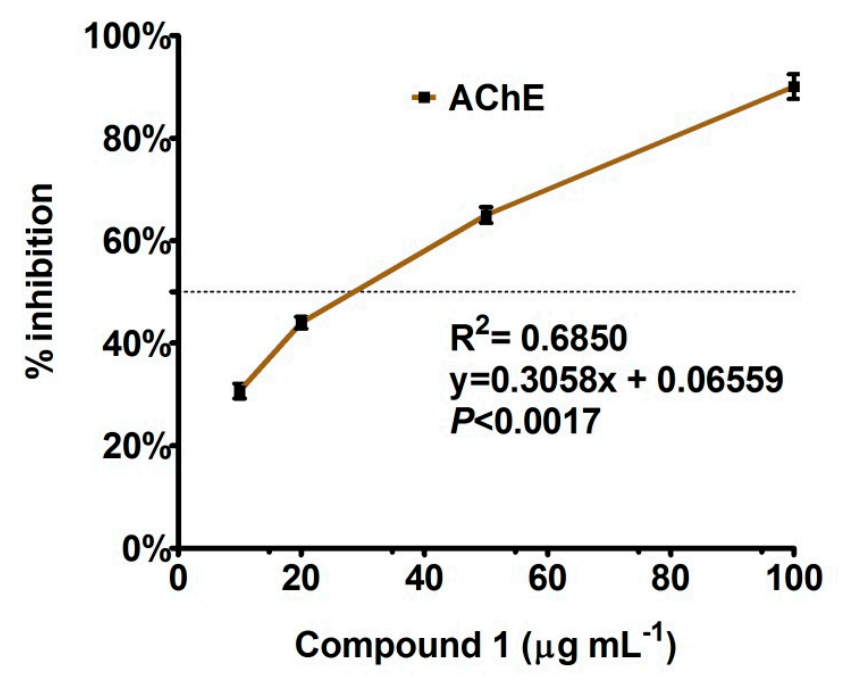

Figure 4. Acetyl cholinesterase inhibition activity of compound 1, isolated from endophytic fungus. The graph showing values of three replications with standard error.

In addition to urease and AChE, we also assessed the potential of bipolarisenol for its anti-lipid peroxidation potential. Lipid peroxidation, a well-established mechanism of cellular injury in plants and animals, is used as an indicator of oxidative stress in cell wall and tissues. Lipid peroxides are unstable and decompose to form a complex series of compounds including reactive carbonyl compounds. 
Polyunsaturated fatty acid peroxides generate malondialdehyde (MDA), as byproduct of lipid disintegration. The results showed that bipolarisenol extended a dose-dependent response towards anti-lipid peroxidation (Figure 5). The new compound also showed a moderate anti-lipid peroxidation potential $\left(\mathrm{IC}_{50}=168.91 \pm 4.23 \mu \mathrm{g} \cdot \mathrm{mL}^{-1}\right)$.

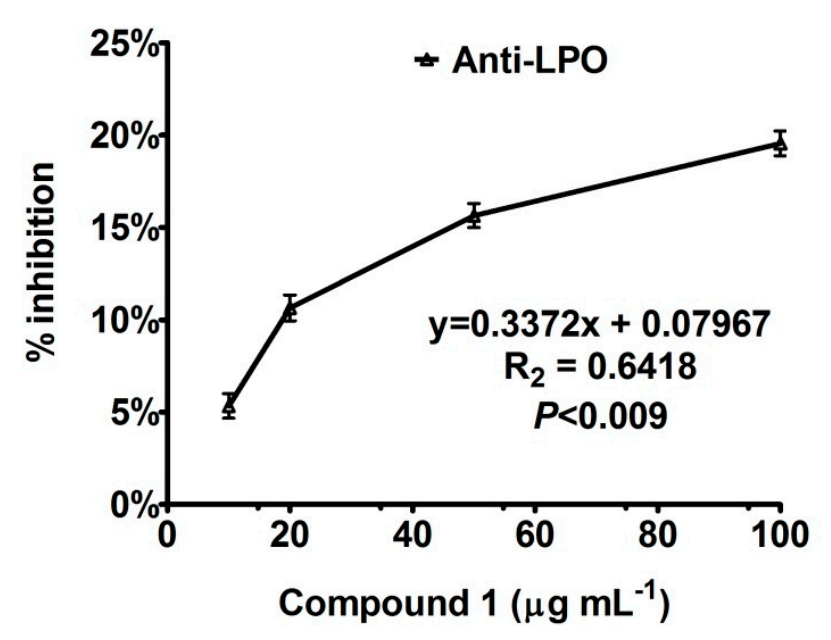

Figure 5. Anti-lipid peroxidation activity of compound 1, isolated from endophytic fungus. The graph showing values of three replications with standard error.

\section{Experimental Section}

\subsection{Endophyte Isolation and Identification}

The leaves of Rhazya stricta, growing in the wild mountains of Jabal Al-Akhdar $\left(23^{\circ} 04^{\prime} 22.00^{\prime \prime} \mathrm{N}\right.$; $57^{\circ} 40^{\prime} 07.00^{\prime \prime} \mathrm{E}$ ), Sultanate of Oman, were detached from the plant. About 20 leaf samples were randomly collected from different trees and were stored in sterilized polythene zip-bag during transportation to the lab. The leaf samples were surface sterilized using the method of Arnold et al. [27]. Briefly, the samples sterilized with $5 \%$ sodium hypochlorite (30 min in a shaking incubator at $120 \mathrm{rpm}$ ) and washed with autoclaved deionized distilled water (DDW) to remove surface contaminants microorganisms. The tissues $\left(1 \mathrm{~mm}\right.$ ) were placed on Hagem media (glucose, $0.5 \% ; \mathrm{KH}_{2} \mathrm{PO}_{4}, 0.05 \%$; $\mathrm{MgSO}_{4} \cdot 7 \mathrm{H}_{2} \mathrm{O}, 0.05 \%$; $\mathrm{NH}_{4} \mathrm{Cl} 0.05 \% ; \mathrm{FeCl}_{3}, 0.1 \%$; streptomycin, 80 ppm; and agar, $1.5 \% ; \mathrm{pH} 5.8 \pm 0.2$ ) to isolate the newly emerging fungal spots. The isolated new fungus (LK12) was further grown on potato dextrose agar (PDA) and Czapek broth (4.5 liters; glucose, $1 \%$; peptone, $1 \% ; \mathrm{KCl}, 0.05 \%$; $\mathrm{MgSO}_{4} \cdot 7 \mathrm{H}_{2} \mathrm{O}, 0.05 \%$; and $\mathrm{FeSO}_{4} \cdot 7 \mathrm{H}_{2} \mathrm{O}, 0.001 \%$; $\mathrm{pH} 7.3 \pm 0.2$; grown for 21 days at shaking incubator, $120 \mathrm{rpm}$; and temperature, $\left.28{ }^{\circ} \mathrm{C}\right)$. The culture was separated through centrifugation $\left(5000 \times \mathrm{g}\right.$ at $4{ }^{\circ} \mathrm{C}$ for $\left.10 \mathrm{~min}\right)$ to obtain culture medium (culture filtrate (CF), 4.5 L) and fungal mycelia (120.4 g), which was lyophilized (Virtis Freeze Dryer, Gardiner, NY, USA) for molecular identification.

Genomic DNA from the fungal mycelia was extracted according to the method of Khan et al. [28]. Fungal endophyte was identified by sequencing the internal transcribed regions (ITS) using universal primers: ITS-1; 5'-TCC GTA GGT GAA CCT GCG G-3' and ITS-4; 5'-TCC TCC GCT TAT TGA TAT GC-3'. The BLAST search program was used to compare the sequence homology of similar nucleotide sequences of ITS region. The closely related sequences obtained were aligned through CLUSTAL W 
using MEGA version 6.06, software [29], and the maximum parsimony tree was constructed using the same software. The bootstrap replications $(1 \mathrm{~K})$ were used as a statistical support for the nodes in the phylogenetic tree.

\subsection{Secondary Metabolite Structure Elucidation}

Optical rotations were measured on a JASCO DIP 360 polarimeter. IR spectra were recorded on a Bruker, ATR-Tensor 37 spectrophotometer. ESI mass spectra were recorded on QSTAR XL (Applied Biosystem). The capillary voltage was maintained between 5 and $5.5 \mathrm{kV}$. The ${ }^{1} \mathrm{H}$ - and ${ }^{13} \mathrm{C}-\mathrm{NMR}$ spectra were recorded on Bruker NMR spectrometers operating at $600 \mathrm{MHz}\left(150 \mathrm{MHz}\right.$ for $\left.{ }^{13} \mathrm{C}\right)$. The chemical shifts values are reported in ppm $(\delta)$ units and the coupling constants $(\mathrm{J})$ are given in Hz. Data are reported as follows: chemical shift (multiplicity (singlet $(\mathrm{s})$, doublet $(\mathrm{d})$, triplet $(\mathrm{t})$, quartet $(\mathrm{q})$ and multiplet $(\mathrm{m})$ ), coupling constants $(\mathrm{Hz})$, and integration). Minor compounds were purified by using recycling preparative High Performance Liquid Chromatography (HPLC) by JAI using silica gel column and 7:3 ethyl acetate/ $n$-hexane systems. For TLC, pre coated aluminum sheets (silica gel 60F-254, E. Merck, Darmstadt, Germany) were used. Visualizations of the TLC plates were achieved under the UV light at 254 and $366 \mathrm{~nm}$, and also by spraying with the ceric sulfate and ninhydrin reagent.

\subsection{Extraction and Isolation}

The mycelial mats and the culture filtrate were extracted completely with ethyl acetate (EtOAc). Both the extracts were compiled and dried over sodium sulfate (anhydrous) and concentrated in vacuo to afford the crude extract $(2.1 \mathrm{~g})$. The EtOAc extract was then subjected to silica gel column chromatography using gradients of ethyl acetate/ $n$-hexane system to afford five fractions (Fr.A to Fr.E). Fr.E was further subjected to recycling preparative HPLC (JAI) analysis. Compound $\mathbf{1}(5.1 \mathrm{mg})$ was purified at a retention time of $23 \mathrm{~min}$ by using ethyl acetate $/ n$-hexane (6:4) in a silica gel column with the flow rate $3.5 \mathrm{~mL} / \mathrm{min}$ after five recycles.

Bipolarisenol (1): colorless amorphous powder. $[\alpha]_{\mathrm{D}}^{30}=-24.2\left(c=0.6, \mathrm{CH}_{3} \mathrm{OH}\right) . \mathrm{UV} \lambda_{\max }\left(\mathrm{CH}_{3} \mathrm{OH}\right): 340$, $264 \mathrm{~nm}$. IR $v_{\max }\left(\mathrm{CH}_{3} \mathrm{OH}\right): 3595,1695$, and $1590 \mathrm{~cm}^{-1} .{ }^{1} \mathrm{H}-\mathrm{NMR}\left(600 \mathrm{MHz}, \mathrm{DMSO}-d_{6}\right), \delta 7.98(1 \mathrm{H}, \mathrm{d}$, $J=1.8 \mathrm{~Hz}, \mathrm{H}-12), 7.24(1 \mathrm{H}, \mathrm{t}, J=7.6 \mathrm{~Hz}, \mathrm{H}-15), 7.18(1 \mathrm{H}, \mathrm{d}, J=14.1 \mathrm{~Hz}, \mathrm{H}-10), 6.82(1 \mathrm{H}, \mathrm{d}$, $J=7.8 \mathrm{~Hz}, \mathrm{H}-16), 6.74$ (1H, d, $J=7.6 \mathrm{~Hz}, \mathrm{H}-14), 6.04$ (1H, dd, $J=3.4 / 6.7 \mathrm{~Hz}, \mathrm{H}-5), 6.03$ (1H, s, H-7), $4.95(1 \mathrm{H}, \mathrm{d}, J=14.1 \mathrm{~Hz}, \mathrm{H}-9), 4.34$ (1H, br s, H-3), 3.15 (1H, m, H-4), 3.01 (1H, m, H-4). ${ }^{13} \mathrm{C}-\mathrm{NMR}$ (150 MHz, DMSO-d6), $\delta 170.4$ (C-1), 169.0 (C-6), 165.0 (C-13), 162.3 (C-8), 137.3 (C-11), 129.8 (C-10), 127.9 (C-15), 126.3 (C-9), 121.4 (C-16), 110.6 (C-12/14), 108.5 (C-5), 96.3 (C-7), 88.2 (C-2), 58.4 (C-3), 35.3 (C-4). EI-MS (70 eV): m/z $302[\mathrm{M}]^{+}, 285[\mathrm{M}-\mathrm{OH}]^{+}, 284\left[\mathrm{M}-\mathrm{H}_{2} \mathrm{O}\right]^{+}, 209[\mathrm{M}-\mathrm{PhOH}]^{+}, 192$ $[\mathrm{M}-\mathrm{PhOH}-\mathrm{OH}]^{+}, 191\left[\mathrm{M}-\mathrm{PhOH}-\mathrm{H}_{2} \mathrm{O}\right]^{+}, 181,111,69$. HR-ESI-MS: $303.1574[\mathrm{M}+\mathrm{H}]^{+}(303.1570$; calculated for $\left.\mathrm{C}_{16} \mathrm{H}_{15} \mathrm{O}_{6}\right), 301.0715[\mathrm{M}-\mathrm{H}]^{-}$(301.0712; calculated for $\left.\mathrm{C}_{16} \mathrm{H}_{13} \mathrm{O}_{6}\right)$.

\subsection{Anti-Lipid Peroxidation and Enzyme Inhibition Assays}

The potential of compounds to inhibit the extent of lipid peroxidation was assessed through a modified method of thiobarbituric acid reactive substances (TBARS) [30]. This was based on the peroxidation of a liposome (phosphatidyl-choline $50 \mathrm{mg} / \mathrm{mL}$ ) induced by iron chloride $(200 \mu \mathrm{L} ; 1 \mathrm{mM})$ 
containing potassium chloride $(300 \mathrm{mM})$ in the presence of sample $(50 \mu \mathrm{L})$. Peroxidation was initiated by ascorbate $(125 \mu \mathrm{L}$ with $0.16 \mathrm{mM})$ and the reaction mixture was incubated for $30 \mathrm{~min}$ at $37{ }^{\circ} \mathrm{C}$. A mixture of trichloroacetic acid $(0.75 \mathrm{~mL}$ with $1.5: 1(v: v))$ and TBA $(0.38 \%)$ was added to the reaction mixture. It was kept in boiling water for 30 min until the pink color appears, which was measured on ELISA at A535. A control without compound was used as negative control while butyl hydroxy toluene (BHT) was used as positive control. The inhibition $(\mathrm{IP} \%=(1-\mathrm{At} / \mathrm{Ao}) \times 100)$; where At and Ao are compound and control absorbance after incubation for $30 \mathrm{~min}$. The experiment was repeated three times.

Urease enzyme inhibition activities of the compound were performed according to the method of Golbabaei et al. [31]. Briefly, a $25 \mu \mathrm{L}$ solution of Jack bean Urease, $55 \mu \mathrm{L}$ of $100 \mathrm{mM}$ urea dissolved in phosphate buffer $\left(0.01 \mathrm{M} \mathrm{K}_{2} \mathrm{HPO}_{4} \cdot 3 \mathrm{H}_{2} \mathrm{O}, 1.0 \mathrm{mM}\right.$ EDTA and $0.01 \mathrm{M} \mathrm{LiCl}_{2} ; \mathrm{pH}$ 8.2) and different concentrations of the compounds $(10,20,50$ and $100 \mu \mathrm{g} / \mathrm{mL})$. The reaction mixture was incubated at $30^{\circ} \mathrm{C}$ for $15 \mathrm{~min}$ in 96 -well plate. The production of ammonia was measured by indophenol method to determine the urease inhibitory activity. The phenol reagent $(45 \mu \mathrm{L}, 1 \% w / v$ phenol and $0.005 \% w / v$ sodium nitroprusside) and alkali reagent $(70 \mu \mathrm{L}, 0.5 \% \mathrm{w} / v$ sodium hydroxide and $0.1 \% \mathrm{NaOCl})$ were added to each well and the increasing absorbance at $630 \mathrm{~nm}$ was measured after $50 \mathrm{~min}$, using an ELISA microplate reader. The change in absorbance per minute was noted. All the tests were performed in triplicate. The percentage inhibition was calculated from the following equation. Inhibitory activity $(\%)=100-($ ODtest well/ODcontrol $) \times 100$. Thiourea was used as the standard inhibitor with $92 \% \pm 1.50 \%$ Inhibition.

Acetyl Cholinestrase (AChE) inhibitory activity of the compound was measured by using method of Ingkaninan et al. [32]. This method is based on the enzyme hydrolyses of substrate acetylthiocholine iodide (ATCI; $15 \mathrm{mM}$ ) resulting in the product thiocholine which reacts with Ellman's reagent 5,5'-dithiobis [2-nitrobenzoic acid] (DTNB; $3 \mathrm{mM}$ ) to produce 2-nitrobenzoate-5-mercaptothiocholine and 5-thio-2-nitrobenzoate, which can be detected at $412 \mathrm{~nm}$. Tris- $\mathrm{HCl}(50 \mathrm{mM}$; pH 8.0) was used as a buffer. AChE used in the assay was from electric eel (type VI-S lyophilized powder, $518 \mathrm{U} / \mathrm{mg}$ solid, and $844 \mathrm{U} / \mathrm{mg}$ protein). The enzyme stock solution $(518 \mathrm{U} / \mathrm{mL})$ was kept at $-80{ }^{\circ} \mathrm{C}$. The further enzyme-dilution was done in $0.1 \%$ BSA in buffer. DTNB was dissolved in Tris buffer $(0.1 \mathrm{M} \mathrm{NaCl}$ and $0.02 \mathrm{M} \mathrm{MgCl}_{2}$ ). ATCI was dissolved in deionized water.

In the 96-well plates with $100 \mu \mathrm{L}$ DTNB, $20 \mu \mathrm{L}$ of $0.26 \mathrm{U} / \mathrm{mL}$ AChE, $40 \mu \mathrm{L}$ buffer $(50 \mathrm{mM}$ Tris $\mathrm{pH}$ 8.0), and $20 \mu \mathrm{L}$ sample in various concentrations dissolved in buffer containing not more than $10 \%$ methanol were added to wells. After mixing, the plate was incubated for $15 \min \left(25^{\circ} \mathrm{C}\right)$ and then the absorbance was measured at $412 \mathrm{~nm}$ in xMark ELISA reader (BioRad, Berkeley, CA, USA). The blank was used without compound in the reaction mixture. The enzymatic reaction was initiated by the addition of $20 \mu \mathrm{L}$ of ATCI and the hydrolysis of acetylthiocholine was monitored by reading the absorbance every $5 \mathrm{~min}$ for $20 \mathrm{~min}$. Galanthamine was used as positive control. All the reactions were performed in triplicate. The percentage inhibition was calculated as follows: Inhibition $(\%)=\mathrm{ES} / \mathrm{E} \times 100$, where, $\mathrm{E}$ is the activity of the enzyme without extract and $\mathrm{S}$ is the activity of enzyme with the extract.

\subsection{Statistical Analysis}

The data shown are the mean values of at least three replicate experiments and expressed as means \pm SD. Statistical analyses were conducted using GraphPad Prism software 5.03 package. 


\section{Conclusions}

Endophytic fungus, Bipolaris sorokiniana LK12, which was isolated from the leaves of alkaloid rich Rhazya stricta, produced a new compound, bipolarisenol. It is the first ever report from this fungus. Furthermore, bipolarisenol was assessed for its potential role in enzyme inhibition of urease and acetyl cholinesterase (AChE), where it showed significantly higher inhibition of AChE activity as compared to urease and anti-lipid peroxidation. The results of the present study may lead to the conclusion that endophytes are considered potential source for novel bioactive products. Thus, the endophytic fungi play an important role in the search for natural compounds as an alternative source for the production of therapeutic agents and bioactive metabolites that are not easily synthesized and have a high activity against pathogenic microorganisms. However, the present study will serve only as a prelude to the more comprehensive studies on the chemistry and biology of the bioactive natural products produced by these endophytes.

\section{Acknowledgments}

The authors are thankful to University of Nizwa Research Fund (A/13-14-UoN/01/Chair MPMNP/IF) and Basic Science Research Program through the National Research Foundation of Korea (NRF) funded by the Ministry of Education (2014R1A1A2A10058022).

\section{Author Contributions}

A.L.K and L.A. performed all the experiments and wrote the manuscript. T.S.R. and J.H. helped in structure elucidation of compound. A.A.-H. edited the manuscript and I.-J.L. helped in identification of the endophytic fungus.

\section{Conflicts of Interest}

The authors declare no conflict of interest.

\section{References}

1. Schulz, B.; Boyle, C. The endophytic continuum. Mycol. Res. 2005, 109, 661-686.

2. Guo, B.; Wang, Y.; Sun, X.; Tang, K. Bioactive natural products from endophytes: A review. Appl. Biochem. Microbiol. 2008, 44, 136-142.

3. Kusari, P.; Kusari, S.; Spiteller, M.; Kayser, O. Endophytic fungi harbored in Cannabis sativa L.: Diversity and potential as biocontrol agents against host plant-specific phytopathogens. Fungal Divers. 2013, 60, 137-151.

4. Gao, J.M.; Xiao, J.; Zhang, Q.; Tang, J.J.; Zhang, A.L.; Gao, Y.Q. Secondary Metabolites from the Endophytic Botryosphaeria dothidea of Melia azedarach and their antifungal, antibacterial, antioxidant, and cytotoxic activities. J. Agric. Food Chem. 2014, 62, 3584-3590.

5. Khan, A.L.; Hussain, J.; Al-Harrasi, A.; Al-Rawahi, A.; Lee, I.J. Endophytic fungi: Resource for gibberellins and crop resistance to abiotic stress. Crit. Rev. Biotechnol. 2015, 35, 62-74. 
6. Schulz, B.; Boyle, C.; Draeger, S.; Römmert, K.; Krohn, K. Endophytic fungi: A source of novel biologically active secondary metabolites. Mycol. Res. 2002, 106, 996-1004.

7. Khan, A.L.; Hamayun, M.; Kim, Y.H.; Kang, S.M.; Lee, I.J. Ameliorative symbiosis of endophyte (Penicillium funiculosum LHL06) under salt stress elevated plant growth of Glycine max L. Plant Physiol. Biochem. 2011, 49, 852-862.

8. Strobel, G.; Daisy, B.; Castillo, U.; Harper, J. Natural products from endophytic microorganisms. J. Nat. Prod. 2004, 67, 257-268.

9. Tan, R.X.; Zou, W.X. Endophytes: A rich source of functional metabolites. Nat. Prod. Rep. 2001, $18,448-459$.

10. Zaman, K.; Perveen, S.; Muzaffar, A.; Choudhary, M.I.; Pervin, A. Alkaloids from Rhazya stricta. Phytochemistry 1991, 30, 1285-1293.

11. Ali, B.H.; Al-Qarawi, A.; Bashir, A.K.; Tanira, M. Phytochemistry, pharmacology and toxicity of Rhazya stricta Decne: A review. Phytother. Res. 2000, 14, 229-234.

12. Gilani, S.A.; Kikuchi, A.; Shinwari, Z.K.; Khattak, Z.I.; Watanabe, K.N. Phytochemical, pharmacological and ethnobotanical studies of Rhazya stricta Decne. Phytother. Res. 2007, 4, 301-307.

13. Sheridan, H.; Canning, A.M. Novel radicinol derivatives from long-term cultures of Alternaria chrysanthemi. J. Nat. Prod. 1999, 62, 1568-1569.

14. Giridharan, P.; Verekar, S.A.; Gohil, A.R.; Mishra, P.D.; Khanna A.; Deshmukh, S.K. Antiproliferative activity of hamigerone and radicinol isolated from Bipolaris papendorfii. BioMed Res. Int. 2014, 2014, 890904.

15. Shaheen, F.; Ali, L.; Ali, S.; Erdemoglu, N.; Sener, B. Antioxidant flavonoids from Tamus communis ssp. Cretica. Chem. Nat. Compd. 2009, 45, 346-349.

16. Dixon, N.E.; Gazzola, C.; Watters, J.J.; Blakeley, R.L. Zerner, B. Inhibition of Jack Bean urease (EC 3.5.1.5) by acetohydroxamic acid and by phosphoramidate: Equivalent weight for urease. J. Am. Chem. Soc. 1975, 97, 4130-4131.

17. Krajewska, B. Ureases I. Functional, catalytic and kinetic properties: A review. J. Mol. Catal. B 2009, 59, 9-21.

18. Burne, R.A.; Chen, Y.Y.M. Bacterial ureases in infectious diseases. Microbes Infect. 2000, 2, 533-542.

19. Krajewska, B.; Zaborska, W. Jack bean urease: The effect of active-site binding inhibitors on the reactivity of enzyme thiol groups. Bioorg. Chem. 2007, 35, 355-365.

20. Covacci, A.; Telford, J.L.; del Giudice, G.; Parsonnet, J.; Rappuoli, R. Helicobacter pylori virulence and genetic geography. Science 1999, 284, 1328-1333.

21. Shabana, S.; Kawai, A.; Kai, K.; Akiyama, K.; Hayashi, H. Inhibitory activity against urease of quercetin glycosides isolated from Allium cepa and Psidium guajava. Biosci. Biotechnol. Biochem. 2010, 74, 878-880.

22. Bae, E.A.; Han, M.J.; Kim, D.H. In vitro anti-Helicobacter pylori activity of some flavonoids and their metabolites. Planta Med. 1999, 65, 442-443.

23. Davies, P.; Maloney, A.J. Selective loss of central cholinergic neurons in Alzheimer's disease. Lancet 1976, 2, 1403.

24. Mangialasche, F.M.; Solomon, A.; Winblad, B.; Mecocci, P.; Kivipelto, M. Alzheimer's disease: Clinical trials and drug development. Lancet Neurol. 2010, 9, 702-716. 
25. Mukherjee, P.K.; Kumar, V.; Mal, M.; Houghton, P.J. Acetylcholinesterase inhibitors from plants. Phytomedicine 2007, 14, 289-300.

26. Murray, A.P.; Faraoni, M.B.; Castro, M.J.; Alza, N.P.; Cavallaro, V. Natural AChE inhibitors from plants and their contribution to Alzheimer's disease therapy. Curr. Neuropharmacol. 2013, 11, 388-413.

27. Arnold, A.E.; Lutzoni, F. Diversity and host range of foliar fungal endophytes: Are tropical leaves biodiversity hotspots? Ecology 2007, 88, 541-549.

28. Torres, M.S.; White, J.F.; Zhang, X.; Hinton, D.M.; Bacon, C.W. Endophyte-mediated adjustments in host morphology and physiology and effects on host fitness traits in grasses. Fungal Ecol. 2012, 5, 322-330.

29. Tamura, K.; Peterson, D.; Peterson, N.; Stecher, G.; Nei, M.; Kumar, S. MEGA5: Molecular evolutionary genetics analysis using maximum likelihood, evolutionary distance, and maximum parsimony methods. Mol. Biol. Evol. 2011, 28, 2731-2739.

30. Gulati, V.; Harding, I.H.; Palombo, E.A. Enzyme inhibitory and antioxidant activities of traditional medicinal plants: Potential application in the management of hyperglycemia. BMC Complement. Altern. Med. 2012, 12, 77, doi:10.1186/1472-6882-12-77.

31. Golbabaei, S.; Bazl, R.; Golestanian, S.; Nabati, R.; Omrany, R.B.; Yousefi, B.; Hajiaghaee, R.; Rezazadeh, S.; Amanlou, M. Urease inhibitory activities of $\beta$-boswellic acid derivatives. Daru 2013, 21, doi:10.1186/2008-2231-21-2.

32. Ingkaninan, K.; Temkitthawon, P.; Chuenchom, K.; Yuyaem, T.; Thongnoi, W. Screening for acetylcholinesterase inhibitory activity in plants used in Thai traditional rejuvenating and neurotonic remedies. J. Ethnopharmacol. 2003, 89, 261-264.

Sample Availability: Samples of the compound $\mathbf{1}$ is available from the authors.

(C) 2015 by the authors; licensee MDPI, Basel, Switzerland. This article is an open access article distributed under the terms and conditions of the Creative Commons Attribution license (http://creativecommons.org/licenses/by/4.0/). 